\title{
Comparative study of the fermentative characteristics of inulin and different types of fibre in rats inoculated with a human whole faecal flora
}

\author{
BY NATHALIE ROLAND, LIONELLE NUGON-BAUDON, CLAUDE \\ ANDRIEUX AND ODETTE SZYLIT \\ Institut National de la Recherche Agronomique, Unité d'Ecologie et Physiologie du Système \\ Digestif, 78352 Jouy-en-Josas, Cedex, France
}

(Received 27 May 1994 - Revised 7 November 1994 - Accepted 6 January 1995)

\begin{abstract}
It is known that the physico-chemical characteristics of fibre modify their fermentation characteristics in the colon. Previously we showed the varying effects of inulin and different types of fibre on the hepatic and intestinal xenobiotic-metabolizing enzymes (XME) in initially germ-free rats inoculated with a human, methanogenic, whole-faecal flora (Roland et al. 1994). The aim of the present work was to assess whether or not these effects could be related to differences in production of fermentation metabolites (gases excreted in vivo and caecal metabolites) due to the different compositions of fibre. The different types of fibres were analysed with regard to their solubility and their composition of neutral monomers and uronic acids. Inulin was totally soluble, carrot (Daucus carota), cocoa (Theobroma cacao) and wheat bran were partially soluble; pea (Pisum sativum) and oat were nearly totally insoluble. Uronic acids were found mostly in carrot and cocoa fibre. Glucose was present as the main neutral monomer in each fibre type. Xylose was found also in wheat bran, pea and oat fibres, and arabinose was found in wheat bran. Inulin consumption led to high levels of $\mathrm{H}_{2}$ production but no $\mathrm{CH}_{4}$ production, to a 4-fold greater caecal concentration of butyrate than with the other fibres and to a decrease in caecal pH. Conversely, rats fed on carrot or cocoa fibre produced a large amount of $\mathrm{CH}_{4}$ but no $\mathrm{H}_{2}$ and generated a different profile of short-chain fatty acids (SCFA). The lowest amounts of gases and SCFA were found in rats fed on wheat bran, pea and oat fibre. We observed a relationship between the caecal concentration of SCFA and the activity of hepatic glutathione-S-transferase $(E C 2.5 .1 .18)$ but no direct link was shown between the other XME and the fermentation profile.
\end{abstract}

Dietary fibre: Fermentation: Gnotobiotic rats

Dietary fibre has been the subject of numerous epidemiological studies which, for the most part, have demonstrated an inverse relationship between high-fibre diets and colon cancer (Burkitt 1971; Reddy et al. 1978; Bingham et al. 1985). Several animal studies have provided evidence that fibre consumption results in protection against chemically-induced large-bowel cancer (Roberts-Andersen et al. 1987; Heitman et al. 1989), although it appears that the protective effect of fibre is highly dependent on the experimental conditions and the type of fibre which is tested (Jacobs, 1986).

Different hypotheses have been proposed to explain the protective effects of fibre against colon cancer (Harris \& Ferguson, 1993). Some authors have suggested that the protective properties of fibre result from dilution of carcinogens with a resultant decrease in their contact with the colonic mucosa (Reddy et al. 1989; Bingham, 1993). A role for the acidification of lumen contents in relation to cell proliferation has also been reported (Jacobs \& Lupton, 1986). Other systems such as the endogenous xenobiotic-metabolizing enzymes (XME), which play a key role in chemical carcinogenesis, could be involved also 
(Smith-Barbaro et al. 1981; Lindeskog et al. 1987). We have shown previously that inulin and five dietary fibres from different sources (carrot (Daucus carota), wheat bran, cocoa (Theobroma cacao), pea (Pisum sativum) and oat) can, in different ways, modify the concentration of cytochrome P-450 and the specific activity of glutathione-S-transferase (EC 2.5.1.18; GSH-T) in the liver and intestine of rats harbouring a human whole-faecal flora (Roland et al. 1994). Although a direct effect of fibre on the intestinal wall during transit is possible, part of the effect on these enzymes, particularly in the liver, could be due to an indirect effect of fibre, through the bacterial metabolites released by its fermentation and then absorbed in the colon. Therefore, the aim of the present study was to investigate this hypothesis and the extent to which bacterial metabolites could be related to changes in the XME system. Different types of dietary fibre are hydrolysed by the digestive microflora in different ways according to their physical and chemical composition and structure, resulting in varying amounts of organic acids and gases (Cummings \& Bingham, 1987). Quantitative and qualitative differences in the production of bacterial metabolites might provide an hypothesis to explain the variability of the effects on the XME and, more generally, on colonic carcinogenesis. To examine this possibility we determined the chemical composition of the different types of fibre and, concurrently with the study of the XME, we compared the profile of the fermentation metabolites, i.e. short-chain fatty acids (SCFA), D- and L-lactic acids, $\mathrm{H}_{2}$ and $\mathrm{CH}_{4}$, in rats consuming the different fibre types. The model of initially germ-free rats subsequently inoculated with a human whole-faecal flora was used to mimic the fermentation profile occurring in the human digestive tract. This model has already been successfully applied to the study of bacterial metabolism and fermentation characteristics (Mallett et al. 1987; Andrieux et al. 1991).

\section{MATERIALS AND METHODS}

Fibre sources

Inulin, extracted from chicory (Tirlemontoise Sugar Refinery, Belgium) and five different sources of dietary fibre were used in the present study: carrot (ARD, Compiègne, France), wheat bran, cocoa seed, pea hull, and oat husks (SOFALIA, Chappes, France). Table 1 shows details of their composition provided by the manufacturer. The amount of total dietary fibre varied according to the source of fibre. Wheat bran contained only $490 \mathrm{~g}$ total fibre $/ \mathrm{kg}$, while in cocoa, oat, carrot, inulin and pea the total fibre contents were 710,800 , $840,860,880 \mathrm{~g} / \mathrm{kg}$ respectively. Inulin consists of soluble fructo-oligosaccharides in which the degree of polymerization ranges from two to eight. For the other fibre sources the relative amounts of soluble and insoluble fractions were determined according to the method of Prosky et al. (1988). For each fraction, neutral monosaccharides were measured by GC after reduction to alditol acetates (Blakeney et al. 1983) and uronic acids were assayed by a colorimetric method (Thibault, 1979).

\section{Diets}

The composition of the diets is indicated in Table 2. Each experimental diet contained one type of fibre and was designed to mimic a 'human-type' diet and still be compatible with rodent digestive physiology. Consequently, fat and protein were derived from both animal sources (lard and fish meal) and vegetable sources (maize oil and soyabean meal). Cellulose, sucrose and a cooked starch (mashed potatoes) were included in all diets. The amount of each fibre source incorporated into the diet was adjusted to give the same amount of added fibre $(100 \mathrm{~g} / \mathrm{kg}$ diet). Slight modifications were made to the amounts of soyabean meal, maize oil and mashed potatoes to produce isonitrogenous and isoenergetic diets. Pelleted diets, packed in double vacuum bags, were sterilized by irradiation at $40 \mathrm{kGy}$. 
Table 1. Composition of experimental fibre sources $(\mathrm{g} / \mathrm{kg})$

\begin{tabular}{|c|c|c|c|c|c|c|}
\hline Fibre source... & Inulin* & $\begin{array}{l}\text { Carrot } \dagger \\
(\text { Daucus } \\
\text { carota })\end{array}$ & $\begin{array}{c}\text { Cocoa } \ddagger \\
\text { (Theobroma } \\
\text { cacao })\end{array}$ & $\begin{array}{l}\text { Wheat } \\
\text { bran } \$\end{array}$ & $\begin{array}{c}\text { Pea } \\
\text { (Pisum } \\
\text { sativum) } \ddagger\end{array}$ & Oat $\ddagger$ \\
\hline $\begin{array}{l}\text { Total fibre } \\
\text { Fibre components } \\
\text { (g/kg total fibre): }\end{array}$ & 860 & 840 & 710 & 490 & 880 & 800 \\
\hline Cellulose & & 320 & 390 & 330 & 680 & 440 \\
\hline Hemicellulose + pectin & & $670 \S$ & 200 & 610 & 250 & 500 \\
\hline Lignin & & 10 & 410 & 60 & 70 & 60 \\
\hline Proteins & 0 & 60 & 140 & 150 & 30 & 50 \\
\hline Lipids & 0 & 0 & 20 & 50 & 0 & 10 \\
\hline Sugars & 120 & 10 & 20 & 160 & 30 & 60 \\
\hline Minerals & 0 & 30 & 50 & 80 & 30 & 30 \\
\hline Water & 20 & 60 & 60 & 70 & 30 & 50 \\
\hline Total & 1000 & 1000 & 1000 & 1000 & 1000 & 1000 \\
\hline
\end{tabular}

* Data provided by Tirlemontoise Sugar Refinery, Belgium.

$\dagger$ Data provided by ARD, Compiègne, France.

\$ Data provided by Sofalia, Chappes, France.

$\S$ Hemicellulose 360 , pectin 310 .

Table 2. Composition of experimental diets ( $\mathrm{g} / \mathrm{kg}$ diet)

\begin{tabular}{|c|c|c|c|c|c|c|}
\hline Diet & Inulin & $\begin{array}{c}\text { Carrot } \\
\text { (Daucus } \\
\text { carota })\end{array}$ & $\begin{array}{c}\text { Cocoa } \\
\text { (Theobroma } \\
\text { cacao })\end{array}$ & Wheat & $\begin{array}{c}\text { Pea } \\
(\text { Pisum } \\
\text { sativum })\end{array}$ & Oat \\
\hline Fibre source & 116 & 119 & 141 & 204 & 114 & 125 \\
\hline Fishmeal & 130 & 130 & 130 & 130 & 130 & 130 \\
\hline Soyabean meal & 130 & 110 & 100 & 80 & 130 & 120 \\
\hline Mashed potatoes & $423 \cdot 5$ & $440 \cdot 5$ & $428 \cdot 5$ & $392 \cdot 5$ & $425 \cdot 5$ & $424 \cdot 5$ \\
\hline Sucrose & 50 & 50 & 50 & 50 & 50 & 50 \\
\hline Cellulose & 70 & 70 & 70 & 70 & 70 & 70 \\
\hline Maize oil & 30 & 30 & 30 & 23 & 30 & 30 \\
\hline Lard & 30 & 30 & 30 & 30 & 30 & 30 \\
\hline Cholesterol & 0.5 & 0.5 & 0.5 & 0.5 & 0.5 & 0.5 \\
\hline Mineral mixture* & 8 & 8 & 8 & 8 & 8 & 8 \\
\hline Vitamin mixture $\dagger$ & 12 & 12 & 12 & 12 & 12 & 12 \\
\hline Energy $(\mathrm{kJ} / \mathrm{kg})$ & 18141 & 18141 & 18141 & 18141 & 18141 & 18141 \\
\hline
\end{tabular}

* Provided the following (mg/kg diet): $\mathrm{Ca}_{2}\left(\mathrm{PO}_{4}\right)_{3} 3040, \mathrm{CaCO}_{3} 1440, \mathrm{~K}_{2} \mathrm{HPO}_{4} 1920, \mathrm{MgSO}_{4} 720, \mathrm{NaCl} 552$, $\mathrm{MgO} 160, \mathrm{FeSO}_{4} .7 \mathrm{H}_{2} \mathrm{O} 68 \cdot 8, \mathrm{ZnSO}_{4} .7 \mathrm{H}_{2} \mathrm{O} 40, \mathrm{MnSO}_{4} . \mathrm{H}_{2} \mathrm{O} 40, \mathrm{CuSO}_{4} .5 \mathrm{H}_{2} \mathrm{O} 8, \mathrm{NaF} 6.4, \mathrm{KCr}\left(\mathrm{SO}_{4}\right)_{2} .12 \mathrm{H}_{2} \mathrm{O} 4$, $\mathrm{Kl} 0 \cdot 32, \mathrm{CoCO}_{3} 0 \cdot 16, \mathrm{MoO}_{4}\left(\mathrm{NH}_{4}\right)_{2} 0 \cdot 16, \mathrm{Na}_{2} \mathrm{SeO}_{3} 0 \cdot 16$.

$\dagger$ Provided the following (mg/kg diet): choline $(500 \mathrm{~g} / \mathrm{kg}) 4200, \alpha$-tocopherol $(340 \mathrm{~g} / \mathrm{kg}) 3000$, ascorbic acid 2000 , myo-inositol 1000 , cyanocobalamin $(1 \mathrm{~g} / \mathrm{kg}) 250$, menadione 100 , thiamin hydrochloride 60 , nicotinic acid 50 , p-aminobenzoic acid 50 , biotin $(20 \mathrm{~g} / \mathrm{kg}) 50$, pyridoxine hydrochloride 40 , pantothenic acid 30 , riboflavin 30 , retinyl acetate $(170 \mathrm{~g} / \mathrm{kg}) 15$, pteroylmonoglutamic acid 10 , cholecalciferol $(2.5 \mathrm{~g} / \mathrm{kg}) 5$, sucrose 1110 .

\section{Animals: inoculation and maintenance}

Germ-free adult male Fischer 344 rats aged 10 weeks and weighing about $280 \mathrm{~g}$ at the beginning of trials were used. The rats, obtained from the INRA (Jouy-en-Josas, France) Breeding unit, were randomly housed, three per cage, in Trexler-type isolators fitted with a rapid transfer system (La Calhène, Vélizy, France). Each animal was inoculated orally 
(oesophagal tubing) with a whole-faecal flora obtained from a healthy adult male subject harbouring a methanogenic microflora and prepared in an anaerobic chamber as described by Roland et al. (1994). Each of the six experimental diets was allocated randomly to the cages (six rats per diet). Animals were given free access to their diets and to sterilized $\left(20 \mathrm{~min}, 120^{\circ}\right)$ tap water. The room temperature was $21^{\circ}$ with a $12 \mathrm{~h}$ light-dark cycle. Animal weight and feed intake were measured once weekly. After 6 weeks on the experimental diets, four rats from each group were placed in individual respiratory chambers for $48 \mathrm{~h}$ in order to measure the production of fermentation gases $\left(\mathrm{H}_{2}\right.$ and $\left.\mathrm{CH}_{4}\right)$. In order to maintain the bacterial status of animals, chambers were connected directly to the isolator (Le Coz et al. 1989).

All procedures were carried out in accordance with the Institute's guide for the care and use of laboratory animals.

\section{Sample collection}

After 8 weeks of exposure to the various dietary regimens, rats were stunned then killed by cervical dislocation. Caecal $\mathrm{pH}$ was immediately measured. Portions of caecal contents were collected and prepared, either by adding $0.1 \mathrm{M}$-triethanolamine $(\mathrm{pH} 9.4 ; 1 \mathrm{ml} / \mathrm{ml}$ caecal contents) to determine lactic acid, or by adding saturated $\mathrm{HgCl}_{2}$ solution $(100 \mu \mathrm{l} / \mathrm{ml}$ caecal contents) in order to determine SCFA. The portions were immediately frozen at $-80^{\circ}$.

\section{Analysis of fermentation metabolites}

$\mathrm{H}_{2}$ and $\mathrm{CH}_{4}$ were determined using a Quintron apparatus (DP-Quintron Instrument, Suresnes, France).

SCFA were determined using GLC after water extraction of the acidified samples. The chromatograph used was a GC 121 Del (Delsi) apparatus with a flame-ionization detector and a semi-capillary SP 1000 column $(15 \mathrm{~m} \times 0.53 \mathrm{~mm})$. Carrier gas $\left(\mathrm{N}_{2}\right)$ flow-rate was $30 \mathrm{ml} / \mathrm{min}$, injector temperature $165^{\circ}$, column temperature $125^{\circ}$ and detector temperature $175^{\circ}$. 2-Ethylbutyric acid was used as an internal standard. The integrator was a Delsi Enica 21 apparatus.

L- and D-lactic acids were determined enzymically using L- or D-lactate dehydrogenase (EC 1.1.1.27; Boehringer Mannheim).

\section{Statistical analysis}

Values were expressed as means with their standard errors. Data were analysed using nested analysis of variance between and within cages so that the variance of the cage component is maintained at zero. Where data were found to have a non-constant variance, analysis was performed on transformed data. Where ANOVA indicated significant treatment effects, treatment means were compared using the Newman-Keuls procedure (Lellouch \& Lazar, 1974). Statistical significance was accepted at $P<0.05$ level.

\section{RESULTS}

\section{Composition of sources of fibre}

Analyses of the different fibres (Table 3) showed that carrot fibre contained soluble and insoluble material in equal amounts. Pea fibre and oat fibre were almost entirely composed of insoluble constituents (about $950 \mathrm{~g} / \mathrm{kg}$ total fibre). In cocoa fibre and wheat bran the amounts of the soluble fraction were intermediate $(320$ and $200 \mathrm{~g} / \mathrm{kg}$ total fibre). Inulin (not indicated in Table 3) contained only soluble fructo-oligosaccharides. In the soluble fraction, uronic acids were present in the carrot fibre and to a lesser extent in the cocoa fibre. Most of them were probably galacturonic acids arising from pectin. Quantitatively, 
Table 3. Composition of soluble $(S F)$ and insoluble (IF) fractions of the different types of dietary fibre* $(\mathrm{g} / \mathrm{kg}$ total fibre $)$

\begin{tabular}{|c|c|c|c|c|c|c|c|c|c|c|}
\hline & \multicolumn{2}{|c|}{$\begin{array}{c}\text { Carrot } \\
\text { (Daucus } \\
\text { carota) }\end{array}$} & \multicolumn{2}{|c|}{$\begin{array}{c}\text { Cocoa } \\
\text { (Theobroma } \\
\text { cacao) }\end{array}$} & \multicolumn{2}{|c|}{ Wheat bran } & \multicolumn{2}{|c|}{$\begin{array}{c}\text { Pea } \\
\text { (Pisum } \\
\text { sativum) }\end{array}$} & \multicolumn{2}{|c|}{ Oat } \\
\hline & $\mathrm{SF}$ & IF & $\mathbf{S F}$ & IF & $\mathrm{SF}$ & IF & SF & IF & SF & IF \\
\hline Fibre fraction & 490 & 510 & 320 & 690 & 200 & 800 & 50 & 950 & 40 & 960 \\
\hline Uronic acids & 240 & 60 & 90 & 50 & 0 & 20 & 10 & 90 & 0 & 20 \\
\hline \multicolumn{11}{|l|}{$\begin{array}{l}\text { Neutral } \\
\text { monosaccharides }\end{array}$} \\
\hline Total & 100 & 320 & 50 & 210 & 40 & 520 & 30 & 570 & 10 & 610 \\
\hline Glucose & 0 & 230 & 10 & 160 & 10 & 170 & 0 & 400 & 0 & 300 \\
\hline Xylose & 0 & 20 & 0 & 10 & 20 & 210 & 0 & 130 & 0 & 270 \\
\hline Arabinose & 30 & 20 & 0 & 10 & 10 & 120 & 10 & 30 & 0 & 30 \\
\hline Galactose & 40 & 30 & 20 & 10 & 0 & 10 & $\mathbf{0}$ & 0 & 0 & 10 \\
\hline Mannose & 10 & 10 & 10 & 20 & 10 & 0 & 10 & 0 & 0 & 0 \\
\hline Rhamnose & 20 & 0 & 10 & 0 & 0 & 0 & 0 & 0 & 0 & 0 \\
\hline Fucose & 0 & 0 & 0 & 0 & 0 & 0 & 0 & 0 & 0 & 0 \\
\hline
\end{tabular}

* For details of analytical procedures, see p. 240.

neutral monomers in the soluble fraction were present in only small amounts; carrot fibre contained the highest amounts of neutral monomers, comprising mostly galactose and arabinose, usually found in araban, galactan and arabinogalactan side-chains of pectic substances. The major proportion of the insoluble fraction comprised neutral monosaccharides. Wheat bran, pea fibre and oat fibre contained larger amounts of neutral sugars than cocoa and carrot fibre. The small amount of cell-wall monomers contained in cocoa fibre resulted from the presence of a large amount of lignin $(410 \mathrm{~g} / \mathrm{kg}$ total fibre, data provided by the manufacturer). In all types of fibre, and particularly in pea fibre, glucose was a major monomer. Although a small amount may have been contributed by hemicellulosic polysaccharides, the bulk of glucose probably arose from cellulose. Wheat bran, pea fibre and oat fibre contained moderate amounts of xylose, originating from hemicelluloses. Wheat bran was also rich in arabinose. The uronic acid content of the insoluble fraction varied from $20-90 \mathrm{~g} / \mathrm{kg}$ total fibre.

\section{Growth and feed intake}

In general, the weight gain of the rats fed on the inulin diet was higher than that of other groups, although this difference was only significant when compared with the carrot group (Table 4). Furthermore, the feed intake of rats fed on inulin was lower when compared with all the other groups. Statistical analysis was not performed on feed intake data since this variable was calculated with only two values (one value/cage of three rats).

\section{Fermentation profile}

Gas production in vivo. Three different fermentation profiles were evident from the results (Table 5). Rats fed on inulin produced almost no $\mathrm{CH}_{4}$ but a very high amount of $\mathrm{H}_{2}$ when compared with the other rats. In contrast, in rats fed on the carrot or cocoa diets the production of $\mathrm{H}_{2}$ was low and the production of $\mathrm{CH}_{4}$ was very high. Finally, the bacterial fermentation of wheat bran, pea fibre and oat fibre produced both $\mathrm{H}_{2}$ and $\mathrm{CH}_{4}$ in small amounts, with the lowest amounts being produced in the case of wheat bran. 
Table 4. The effect of type of dietary fibre on growth and feed intake of germ-free rats inoculated with human whole-faecal flora*

(Mean values with their standard errors for six rats)

\begin{tabular}{|c|c|c|c|c|}
\hline \multirow[b]{2}{*}{ Diet $\dagger$} & \multicolumn{2}{|c|}{ Weekly wt gain $(\mathrm{g})$} & \multicolumn{2}{|c|}{ Weekly feed intake $(\mathrm{g})$} \\
\hline & Mean & SEM & Mean & SEM \\
\hline Inulin & $13 \cdot 5^{\mathrm{a}}$ & $1 \cdot 5$ & $111 \cdot 1$ & $2 \cdot 1$ \\
\hline Carrot (Daucus carota) & $9 \cdot 4^{b}$ & 0.7 & 130.8 & $2 \cdot 4$ \\
\hline Cocoa (Theobroma cacao) & $10 \cdot 5^{\mathrm{ab}}$ & 0.6 & 128.8 & 0.8 \\
\hline Wheat bran & $12 \cdot 1^{\mathrm{ab}}$ & 0.7 & $127 \cdot 2$ & $1 \cdot 2$ \\
\hline Pea (Pisum sativum) & $10 \cdot 9^{\mathrm{ab}}$ & 0.6 & $121 \cdot 5$ & $1 \cdot 3$ \\
\hline Oat & $11 \cdot 0^{\mathrm{ab}}$ & 0.6 & 125.2 & $0 \cdot 0$ \\
\hline
\end{tabular}

a, b Within a vertical column, means with unlike superscript letters were significantly different $(P<0 \cdot 05)$.

* For details of procedures, see pp. 240-242.

$\dagger$ For details of composition, see Table 2.

$\ddagger$ Means expressed per rat, calculated from two values ( $n$ two cages).

Table 5. The effect of type of dietary fibre on gas production $(\mathrm{ml} / 24 \mathrm{~h}$ per $10 \mathrm{~g}$ feed intake per $\mathrm{kg}$ body wt) by germ-free rats inoculated with human whole-faecal flor $a^{*}$

(Mean values with their standard errors for four rats)

\begin{tabular}{|c|c|c|c|c|}
\hline \multirow[b]{2}{*}{$\operatorname{Diet} \uparrow$} & \multicolumn{2}{|c|}{$\mathrm{H}_{2}$} & \multicolumn{2}{|c|}{$\mathrm{CH}_{4}$} \\
\hline & Mean & SEM & Mean & SEM \\
\hline Inulin & $44 \cdot 5^{a}$ & $12 \cdot 0$ & $0 \cdot 6^{\mathrm{a}}$ & $0 \cdot 2$ \\
\hline Carrot (Daucus carota) & $2 \cdot 6^{\mathrm{b}}$ & 0.5 & $49 \cdot 0^{\mathrm{b}}$ & $2 \cdot 8$ \\
\hline Cocoa (Theobroma cacao) & $1 \cdot 8^{b}$ & 0.6 & $57 \cdot 7^{b}$ & $14 \cdot 6$ \\
\hline Wheat bran & $1 \cdot 7^{\mathrm{b}}$ & $0 \cdot 3$ & $0 \cdot 0^{\mathrm{a}}$ & $0 \cdot 0$ \\
\hline Pea (Pisum sativum) & $2 \cdot 6^{\mathrm{b}}$ & 1.9 & $15 \cdot 2^{\mathrm{a}}$ & $5 \cdot 8$ \\
\hline Oat & $2 \cdot 0^{\mathrm{b}}$ & 0.6 & $9 \cdot 3^{a}$ & 0.7 \\
\hline
\end{tabular}

a, b Within each vertical column, means with unlike superscript letters were significantly different $(P<0.05)$.

* For details of procedures, see pp. 240-242.

$\dagger$ For details of composition, see Table 2.

Caecal pH and caecal concentrations of bacterial metabolites. Compared with all other fibre types, inulin consumption lowered caecal $\mathrm{pH}$ and, when compared with wheat bran, pea fibre and oat fibre, significantly enhanced the caecal concentration of total SCFA (Table 6). In relation to the three major SCFA, rats fed on inulin had a large concentration of butyrate, which was about 4-fold higher than that of all other animals. Caecal concentration of acetate in the inulin group was similar to that of rats fed on the carrot fibre or the cocoa fibre but was significantly higher than that of the rats fed on pea fibre or oat fibre. Caecal concentrations of propionate were not affected by diet. When the $C_{2}: C_{3}: C_{4}$ profile (expressed relative to the total amounts of the three SCFA) is considered, inulin fermentation produced a higher proportion of butyrate and lower proportions of acetate and propionate than the other types of fibre. Among the five other fibres, both carrot and cocoa were different from pea and oat, with a higher proportion of acetate and a lower proportion of propionate. The profile of wheat bran was intermediate between them. As far as the minor SCFA are concerned, caecal concentrations of valerate and isovalerate were 


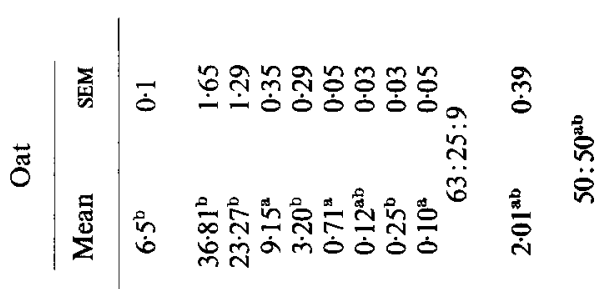

3

క్ర

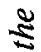

.5

帘

菑

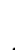

密

공

8 व

$\checkmark$

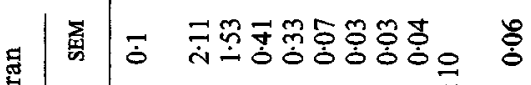

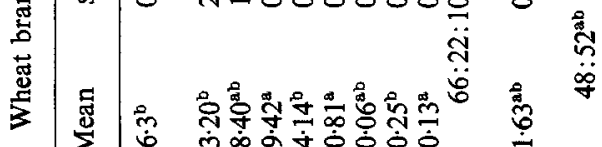

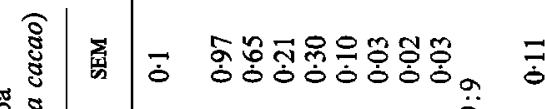

ชั

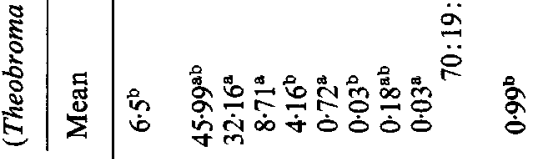

일

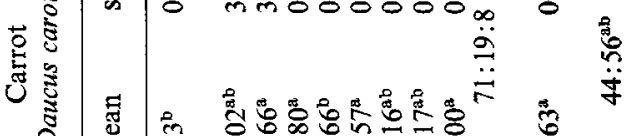

๑

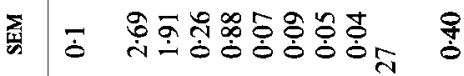

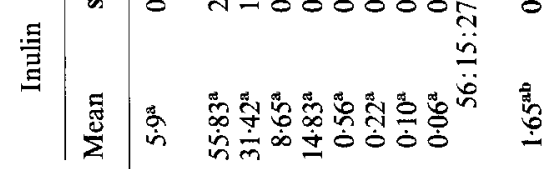

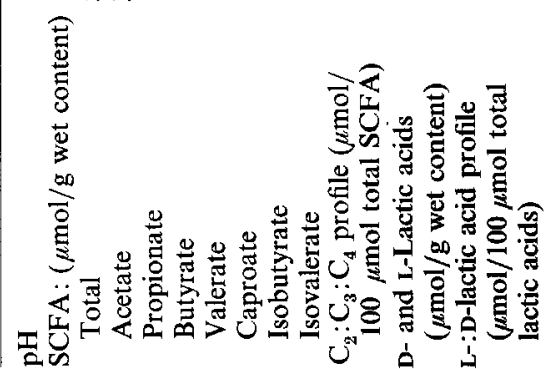


not affected by diet. Inulin consumption led to a higher concentration of caproate (significant with cocoa) and a lower concentration of isobutyrate (significant with wheat bran, pea and oat).

In the case of caecal $\mathrm{D}$ - and $\mathrm{L}$-lactic acids the total concentration was significantly higher in rats fed on the carrot-fibre diet than that in animals fed on the cocoa-fibre or pea-fibre diets. The proportion of L- and D-acids was also modified: the proportion of D-lactic acid was significantly lower in rats fed on the pea fibre $(0.45)$ compared with that for the rats fed on the inulin or cocoa fibre (0.60).

\section{DISCUSSION}

The different types of undigestible polysaccharides used for the present study can be divided into three subgroups with respect to their solubility. Inulin must be considered in a category on its own since it was totally soluble. Pea fibre and oat fibre on the other hand were almost totally insoluble. Oat fibre, prepared from husks, was rich in cellulose and insoluble xylans and, therefore, was very different from oat bran which is rich in soluble fibre (Englyst et al. 1989). Pea fibre contained a large amount of cellulose. Previous work suggests that the uronic acids found in the insoluble fraction of the pea hull were probably galacturonic acids originating from non-solubilized pectin, highly linked with cellulose and acidic xylans of the cell wall (Ralet et al. 1993; Salvador et al. 1993). Wheat bran, cocoa fibre and carrot fibre belong to a third intermediate group showing partial solubility. Carrot and cocoa are similar in the sense that they contained soluble pectic substances and a low amount of hemicellulosic pentoses. However, unlike carrot, cocoa fibre was rich in lignin. Wheat bran contained a large amount of pentosans and shares some characteristics with the non-soluble oat fibre because of the absence of pectin.

Production of fermentation metabolites varied both qualitatively and quantitatively according to the chemical composition of the polysaccharides. Fermentation of inulin is a unique case with regard to the high production of $\mathrm{H}_{2}$, the suppression of the excretion of $\mathrm{CH}_{4}$, the high concentration of caecal butyrate and the acidification of the caecum. These results are in agreement with those reported by Andrieux et al. (1991) in heteroxenic rats. An increased production of butyrate was not observed in the caecum of conventional rats fed on inulin (Levrat et al. 1991) and this seems to be specific to fermentation by the human microflora. Apparently, an enhanced acidity of the caecum is related to an increased amount of total SCFA, particularly butyrate, and not of D- and L-lactic acids. Nevertheless, other fermentation metabolites that were not determined here (such as formic or succinic acids) could also be responsible for this decrease in $\mathrm{pH}$.

Fermentation of carrot and cocoa fibres differed from that of inulin in relation to the observed high $\mathrm{CH}_{4}$ and low $\mathrm{H}_{2}$ production and the SCFA profile they generated. Except for caecal concentrations of $\mathrm{D}$ - and L-lactic acids, the fermentation of these two fibres is very similar. The presence of a high amount of lignin in cocoa fibre does not seem to influence the degree of fermentation. It appears that a chronic consumption of soluble pectic substances promotes $\mathrm{CH}_{4}$ production by human flora isolated from a methanogenic donor and inoculated into the rat. This point was also illustrated by Szylit \& Andrieux (1993). The profile of gas production obtained with inulin, carrot and cocoa is in agreement with the observations of Bjorneklett \& Jenssen (1982) who found that production of these two gases was not simultaneously high.

The results of the present study confirm the relationship usually demonstrated between high solubility and high fermentability (Roberfroid, 1993). In contrast to inulin, carrot and cocoa fibre, the insoluble oat and pea fibres led to the lowest caecal concentrations of SCFA and lowest gas production. Uronic acids contained in the highly-linked pectic substances 
in the insoluble cell wall do not lead to high $\mathrm{CH}_{4}$ production and probably remain inaccessible to the bacteria. However, the amount of soluble fibre, determined in the Association of Official Analytical Chemists (Prosky et al. 1988) method, which is not likely to reflect the actual solubility in the colonic lumen, is not a sufficient criterion to predict the degree of fermentation. For example, wheat bran which contains $200 \mathrm{~g}$ soluble material $/ \mathrm{kg}$ yielded very little gas production. Caecal concentrations of $\mathrm{D}$ - and L-lactic acids also seem to be independent of the solubility of the fibre. In addition to the chemical composition of fibre, other variables, such as their molecular structure or physical properties, probably influence the degradative attack by bacterial enzymic systems (Eastwood et al. 1986; Selvendran, 1990).

Food conversion efficiency was higher with rats fed on the inulin diet $(0.12 v .0 .7-0.9$ with the other fibres). This could partly be the result of the high production of SCFA which could provide more energy for use by the organism (Bergman, 1990). Moreover, unlike inulin which is composed of oligosaccharides, the other complex fibres could also be more likely to decrease nutrient absorption in the small intestine.

Chronic consumption of inulin and these five types of fibre led to varying effects on the XME system, i.e. hepatic cytochrome P-450 and hepatic and colonic GSH-T (Roland et al. 1994). No changes in the GSH-T were observed in the small intestine, i.e. in a site where no fermentation occurs. In the colon we observed a lower specific activity of the GSH-T in rats fed on wheat bran compared with those fed on oat or cocoa fibre. Inulin did not act in a significantly different way to the five other fibres. Apparently, at the site of fermentation there was not a direct relationship between the fermentation characteristics investigated in the present study and the changes in GSH-T. Indeed, oat fibre and wheat bran, which share a very similar fermentation profile, have a different effect on this enzyme. However, bacterial metabolites were measured in the caecal contents. From the caecum to the colon changes in fermentation and absorption may occur, resulting in slightly different profiles of metabolites at these two sites. The highest specific activity of GSH-T was observed in the liver of rats fed on inulin and the lowest in rats fed on wheat bran, pea and oat fibre. Intermediate values were found with carrot and cocoa fibre. These findings seem to indicate an apparent relationship between hepatic GSH-T activity and the degree of solubility of the fibres and, therefore, with the amount of total SCFA produced by fermentation. Whether the changes in enzyme activity could be a consequence of the production of these metabolites is hypothetical but it is known that they are readily absorbed in the caecum and metabolized in the liver (Bergman, 1990). On the other hand, the changes in hepatic P-450 appears to be independent of bacterial metabolites. Pea and oat fibres, which were similar with regard to fermentation characteristics, have very distinct effects on isoenzymic forms of P-450.

In this preliminary study it was not possible to establish a direct relationship between changes in XME and the nature of the bacterial metabolites produced from fermentation of fibre. Further experiments with gnotobiotic animals are necessary to investigate thoroughly the involvement of the intestinal bacteria in changes in the XME system associated with different fibre types.

This work was supported by grants from the French Ministries of Agriculture and Forestry, and of Research and Technology, and from Group Danone (France). The authors thank Jean-François Thibault and Marie-Jeanne Crépeau (INRA, Nantes, France) for their contribution to the analysis of the different fibres. They thank Christiane Mercier and Jean-Michel Antoine (Group Danone, Paris, France) for their useful advice. They are grateful to Alan Duncan (Macaulay Land Use Research Institute, Aberdeen, UK) for his careful reading of the manuscript. 


\section{REFERENCES}

Andrieux, C., Lory, S., Dufour-Lescoat, C., de Baynast, R. \& Szylit, O. (1991). Physiological effects of inulin in germ-free rats and in heteroxenic rats inoculated with a human fecal flora. Food and Hydrocolloids 5, 49-56.

Bergman, E. N. (1990). Energy contributions of volatile fatty acids from the gastrointestinal tract in various species. Physiological Reviews 70, 567-590.

Bingham, S. A. (1993). Plant cell wall material and cancer protection. In Food and Cancer Prevention: Chemical and Biological Aspects, pp. 339-347 [K. W. Waldron, I. T. Johnson and G. R. Fenwick, editors]. Cambridge: The Royal Society of Chemistry.

Bingham, S. A., Williams, D. R. R. \& Cummings, J. H. (1985). Dietary fibre consumption in Britain: new estimates and their relation to large bowel cancer mortality. British Journal of Cancer 52, 399402.

Bjorneklett, A. \& Jenssen, E. (1982). Relationships between hydrogen $\left(\mathrm{H}_{2}\right)$ and methane $\left(\mathrm{CH}_{4}\right)$ production in man. Scandinavian Journal of Gastroenterology 17, 985-992.

Blakeney, A. B., Harris, P. J., Henry R. J. \& Stone, B. A. (1983). A simple and rapid preparation of alditol acetates for monosaccharide analysis. Carbohydrates Research 113, 291-299.

Burkitt, D. P. (1971). Epidemiology of cancer of the colon and the rectum. Cancer 28, 3-13.

Cummings, J. H. \& Bingham, S. A. (1987). Dietary fibre, fermentation and large bowel cancer. Cancer Surveys 6, 601-621.

Eastwood, M. A., Brydon, W. G. \& Anderson, D. M. W. (1986). The effect of the polysaccharide composition and structure of dietary fibers on cecal fermentation and fecal excretion. American Journal of Clinical Nutrition 44, 51-55.

Englyst, H. N., Bingham, S. A., Runswick, S. A., Collinson, E. \& Cummings, J. H. (1989). Dietary fibre (nonstarch polysaccharides) in cereal products. Journal of Human Nutrition and Dietetics 2, 253-271.

Harris, P. J. \& Ferguson, L. R. (1993). Dietary fibre: its composition and role in protection against colorectal cancer. Mutation Research 290, 97-110.

Heitman, D. W., Ord, V. A., Hunter, K. E. \& Cameron, I. L. (1989). Effect of dietary cellulose on cell proliferation and progression of 1,2-dimethylhydrazine-induced colon carcinogenesis in rats. Cancer Research 49, 5581-5585.

Jacobs, L. R. (1986). Relationship between dietary fiber and cancer: metabolic, physiologic, and cellular mechanisms. Proceedings of the Society for Experimental Biology and Medicine 183, 299-310.

Jacobs, L. R. \& Lupton, J. R. (1986). Relationship between colonic luminal pH, cell proliferation, and colon carcinogenesis in 1,2-dimethylhydrazine treated rats fed high fiber diets. Cancer Research 46, $1727-1734$.

Le Coz, Y., Morel, M. T., Bousseboua, H., Dufour, C. \& Szylit, O. (1989). Mise au point d'une chambre respiratoire connectée sur isolateur pour la mesure in vivo des gaz de fermentation chez l'animal gnotoxénique (Development of a respiratory chamber and its connexion with an isolator: a method to measure the in vivo production of fermentation gas by gnotobiotic animals). Sciences et Technologie des Animaux de Laboratoire 14, 35-39.

Lellouch, J. \& Lazar, P. (1974). Méthodes Statistiques en Expérimentation Biologique. Collection Statistique en Biologie et en Medecine. Paris: Médecine-Sciences, Flammarion.

Levrat, M. A., Rémésy, C. \& Demigné, C. (1991). High propionic acid fermentations and mineral accumulation in the cecum of rats adapted to different levels of inulin. Journal of Nutrition 121, 1730-1737.

Lindeskog, P., Övervik, E., Hansson, T. \& Gustafsson, J. A. (1987). Influence of dietary fibre on hepatic and intestinal metabolism in rat. Scandinavian Journal of Gastroenterology 129, Suppl., 258-262.

Mallett, A. K., Bearne, C. A., Rowland, I. R., Farthing, M. J. G., Cole, C. B. \& Fuller, R. (1987). The use of rats associated with a human faecal flora as a model for studying the effects of diet on the human gut microflora. Journal of Applied Bacteriology 63, 39-45.

Prosky, L., Asp, N. G., Schweizer, T. F., DeVries, J. W. \& Furda, I. (1988). Determination of insoluble, soluble, and total dietary fiber in foods and food products : interlaboratory study. Journal of the Assaciation of Official Analytical Chemists 71, 1017-1023.

Ralet, M. C., Della Valle, G. \& Thibault, J. F. (1993). Raw and extruded fibre from pea hull. Part I: Composition and physico-chemical properties. Carbohydrate Polymers 20, 17-23.

Reddy, B., Engle, A., Katsifis, S., Simi, B., Bartram, H. P., Perrino, P. \& Mahan, C. (1989). Biochemical epidemiology of colon cancer: effect of types of dietary fiber on fecal mutagens, acid, and neutral sterols in healthy subjects. Cancer Research 49, 4629-4635.

Reddy, B. S., Hedges, A. R., Laakso, K. \& Wynder, E. L. (1978). Metabolic epidemiology of large bowel cancer. Fecal bulk and constituents of high-risk North American and low-risk Finnish population. Cancer $\mathbf{4 2}$, 2832-2838.

Roberfroid, M. (1993). Dietary fiber, inulin, and oligofructose: a review comparing their physiological effects. Critical Reviews in Food Science and Nutrition 33, 103-148.

Roberts-Andersen, J., Mehta, T. \& Wilson, R. B. (1987). Reduction of DMH-induced colon tumors in rats fed psyllium husk or cellulose. Nutrition and Cancer 10, 129-136.

Roland, N., Nugon-Baudon, L., Flinois, J. P. \& Beaune, P. (1994). Hepatic and intestinal cytochrome P-450, glutathione-S-transferase and UDP-glucuronosyl transferase are affected by six types of dietary fiber in rats inoculated with a human whole fecal flora. Journal of Nutrition 124, 1581-1587.

Salvador, V., Cherbut, C., Barry, J. L., Bertrand, D., Bonnet, C. \& Delort-Laval, J. (1993). Sugar composition of 
dietary fibre and short-chain fatty acid production during in vitro fermentation by human bacteria. British Journal of Nutrition 70, 189-197.

Selvendran, R. R. \& Robertson, J. A. (1990). The chemistry of dietary fibre. An holistic view of the cell wall matrix. In Dietary Fibre: Chemical and Biological Aspects, pp. 27-43 [D. A. T. Southgate, K. Waldron, I. T. Johnson and G. R. Fenwick, editors]. London: Royal Society of Chemistry.

Smith-Barbaro, P. A., Hanson, D. \& Reddy, B. S. (1981). Effect of bran and citrus pulp on hepatic, small intestinal, and colonic mucosal cytochromes P-450 and b5 levels in rats. Journal of Nutrition 111, $789-797$.

Szylit, O. \& Andrieux, C. (1993). Physiological and pathophysiological effects of carbohydrate fermentation. In Intestinal Flora, Immunity, Nutrition and Health. World Review of Nutrition and Dietetics, vol. 74, pp. 88-122 [A. P. Simopoulos, T. Corring and A. Rérat, editors]. Basel: Karger.

Thibault, J. F. (1979). Automatisation du dosage des substances pectiques par la méthode au métahydroxydiphényl (Automatization of the assay of pectic substances by the metahydroxy-phenyl method). LebensmittelWissenschaft und Technologie 12, 247-251. 